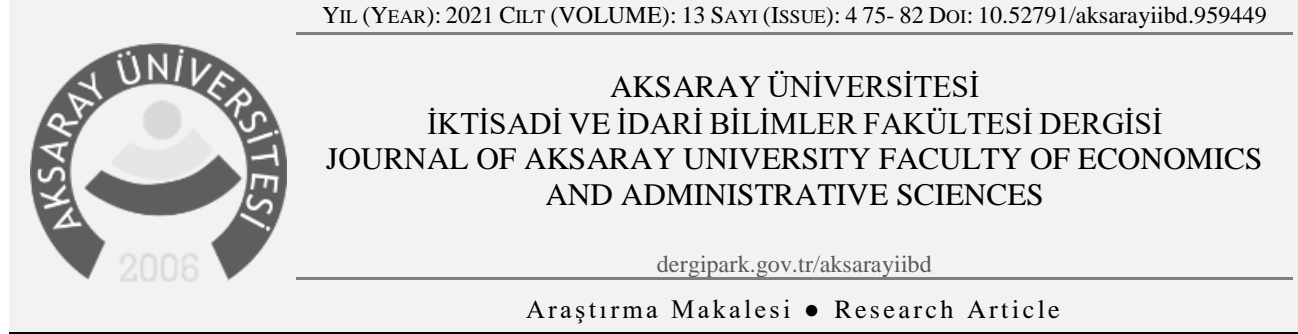

\title{
Yozlaşma, Kamusal Etkililik ve Ekonomik Büyüme: OECD Ülkeleri Üzerinde Bir Araştırma
}

\section{Corruption, Public Effectiveness and Economic Growth: A Study on OECD Countries}

\section{Gülsüm Gürler Hazman ${ }^{1}$}

${ }^{1}$ Prof. Dr., Afyon Kocatepe Üniversitesi, İktisadi ve İdari Bilimler Fakültesi, Maliye Bölümü, gghazman@aku.edu.tr, Orcid ID: 0000-00029953-4330

\begin{tabular}{|c|c|}
\hline M A K A L E B İ L G İ S İ & $\ddot{O ̈ Z E T}$ \\
\hline $\begin{array}{l}\text { Makale Geçmişi: } \\
\text { Geliş Tarihi: } 29 \text { Haziran } 2021 \\
\text { Kabul Tarihi: } 10 \text { Aralık } 2021\end{array}$ & $\begin{array}{l}\text { Kamusal etkililik, kamusal hizmet açısından amaçları elde etme başarısı olarak ifade edilmektedir. Kamu } \\
\text { hizmetlerinin başarısının değerlendirilmesinde sunulan hizmet ile kamuya ve yararlanıcılarına sağlanan } \\
\text { faydalara bakılmaktadır. Kamusal etkililik ile yolsuzluk ilişkisinin bilinmesi, yolsuzluğu etkileyen } \\
\text { unsurların tahmin edilmesinde önemlidir. Bu çalışmanın amacı kamusal etkililiğin, büyümenin ve } \\
\text { işsizliğin yozlaşma üzerindeki etkisinin Türkiye dahil } 33 \text { OECD ülkesi için 2004-2015 verilerini } \\
\text { kullanarak panel veri ile test etmektir. Çalışmadan elde edilen analitik sonuçlara göre kamusal etkililik, } \\
\text { yozlaşma (yolsuzluk algılama endeksi) üzerinde istatistiksel olarak anlamlı ve pozitif yönlü bir etkiye } \\
\text { sahiptir. Yolsuzluk algı endeksi büyüdükçe yozlaşma azaldığına göre; kamusal etkililik arttıkça yozlaşma } \\
\text { da azalmaktadır. Kişibaşına GSYİH ise yolsuzluk algılama endeksi üzerinde istatistiksel olarak anlamlı } \\
\text { ve pozitif katsayıya sahip olduğundan, elde edilen sonuçlara göre ekonomiler büyüdükçe yozlaşmalar da } \\
\text { azalmaktadır. }\end{array}$ \\
\hline A R T I C LE I N F O & A BST RA C T \\
\hline $\begin{array}{l}\text { Keywords } \\
\text { Public effectiveness, } \\
\text { Corruption, } \\
\text { GDP per Capita }\end{array}$ & $\begin{array}{l}\text { Public effectiveness is defined as the success of achieving the goals of public service. In the evaluation } \\
\text { of the success of public services, the service provided and the benefits provided to the public and its } \\
\text { beneficiaries are considered. The relationship between public effectiveness and corruption is important } \\
\text { in estimating the factors affecting corruption. The aim of this study to test the effect of public } \\
\text { effectiveness, growth and unemployment on corruption with panel data using 2004-2015 data for } 33 \\
\text { OECD countries, including Turkey. According to the analytical results obtained from the study; public } \\
\text { effectiveness has a statistically significant and positive effect on corruption (corruption perception index). }\end{array}$ \\
\hline $\begin{array}{l}\text { Article History: } \\
\text { Received: } 29 \text { June } 2021 \\
\text { Accepted: } 10 \text { December } 2021\end{array}$ & $\begin{array}{l}\text { As corruption perception index increases, corruption decreases means that as public effectiveness } \\
\text { increases, corruption decreases. Since GDP per capita has a statistically significant and positive } \\
\text { coefficient on the corruption perception index, according to the results as economies grow, corruption } \\
\text { decreases. }\end{array}$ \\
\hline
\end{tabular}

$\mathrm{K}$ amu hizmetinde etkililik ve etkinlik tartışmaları birçok ülkede devletin kamu politikalarının etkilerinin tartışılmasına neden olmuştur. Devletin Keynesyen ekonomi politikalarının da etkisiyle 1929 Buhranından sonra yetki ve sorumlulukları artmıştır. Keynesyen ekonomi politikalarının etkisiyle devletler ekonomik ve sosyal politikalarda daha etkin rol almış ve kamu hizmetleri çeşitlenmiş ve kamusal kaynaklar büyümüştür. İlerleyen dönemde Keynezyen politikalar 1970'lerin sonunda ortaya çıkan petrol krizi ve stagflasyon ile birlikte sorgulanmaya başlamıştır. Bu dönemde özellikle küresel ekonomi ve dolayısıyla da kamu harcamaları üzerinde baskı artmış ve bütçe açıklarının etkisiyle geleneksel kamu yönetiminin çözüm olmada yeterli olmadı̆̆ hakkındaki genel algı ile kamu yönetimini yeniden yapılandırma yani reform niteliği taşıyan "Yeni Kamu Yönetimi İşletmeciliği (YKI)" gündeme gelmiştir. Bu anlayış özel sektörde yaygın olan saydamlık, hesap verebilirlik, kalite gibi değerlerin kamu sektörüne uyarlanmasından ibarettir. Kamu hizmetinde de vatandaş odaklılık olarak 
ifade ettiğimiz vatandaşın tercihlerini dikkate alan ve sonuç odaklı yaklaşımlar ön plana çıkmıştır. YKİ, kamu hizmetinin etkili ve etkin sunumunu sağlama amacını güden bir anlayış ile kamu sektöründe değişim sürecini hedeflemektedir.

Kamu bütçesinin sürdürülemez şekilde bütçe açıkları ile sonuçlanması, kamusal kaynakların verimsiz alanlara kaymasına neden olabilir. Çünkü kronik bütçe açıklarının kolay finansman yöntemi olarak borçlanma ile finansmanı, ileriki dönemlerde alınan fonun verimli kullanılıp kullanılmadığına bağlı olarak mali sorunları beraberinde getirebilir. Özellikle kamu kesiminin bürokratik açıdan yetersiz ve etkinsiz olduğu az gelişmiş ülkelerde, israf ve savurganlık daha ileri boyutta yaşandığından mali sorunlar daha sık ortaya çıkabilir. Bu durum, ekonomik ve politik yozlaşmaları arttırabilir ve kamunun başarısızlığı ile sonuçlanarak, kamuya duyulan güveni de olumsuz etkileyebilir. Bu süreçte kamu yönetimini yeniden yapılandırma adına çeşitli öneriler getirilmektedir. Bu önerilerden birisi ise kamusal etkinliği ve etkililiği arttırmaktır.

Bu amaçla çalışmada yozlaşma, kamusal etkililik ve büyüme ilişkisini ortaya koymak amaciyla 2004-2015 dönemini kapsayan panel veri ile OECD ülkeleri baz alınarak, regresyon modeli kurulmuştur. Yozlaşmanın bağımlı değişken olarak ele alındığı çalışmalarda kullanılan diğer açıklayıcı değişkenler dikkate alınarak; işsizlik ve kişibaşına GSMH modele dahil edilmiştir. Değişkenler arasında eşbütünleşme ilişkisinin varlığını kanıtlayan Westerlund (2007) testinden sonra panel AMG sonuçlarına göre; analize dahil edilen ülkeler açısından ekonomi büyüdükçe yani kişibaşına GSYİH arttıkça yozlaşma düzeyi gerilemektedir. Dolayısıyla ekonomik büyüme yozlaşmayı azaltmaktadır. Diğer taraftan kamusal etkililik düzeyi artarsa yozlaşma da azalmaktadır.

\section{LITERATÜR TARAMA}

Yozlaşma kavramının tanımlanmasında tek tip tanımlama yapmak güçtür, birden çok tanım söz konusudur. Yozlaşmaya neden olan faktörler çeşitlidir ve yozlaşmanın gerçekleştiği ortam ve örgütlerin farklı olması, sonuçlarının farklı olması nedeniyle yolsuzlukla ilgili tanımlar çeşitlidir. Yozlaşma genel olarak kamu kaynaklarının özel bir çıkar amacıyla kötüye kullanılması olarak tanımlanmaktadır (https://www.worldbank.org/en/topic/governance/brief/anti-corruption, 30. 05.2021).

Yozlaşma sorunu hem gelişmiş hem de gelişmekte olan ülkelerde yaygın bir şekilde görülen küresel bir problem olarak karşımıza çıkan bir durumdur. Genel olarak yozlaşma, bir kişinin hem parasal hem de parasal olmayan özel bir kazanç veya gayri resmi bir amaç için görevini kötüye kullanması anlamına gelmektedir (Karahan, 2019: 2918). Yozlaşma ile ilgili yapılan araştırmalar, yozlaşmanın ekonomik ve sosyal etkilerine odaklanmakta ve ulusların ekonomik büyüme ve gelişmesini engellediği ve dolayısıyla sosyal istikrara zarar verdiğini açıklamaktadır. Yozlaşmanın liyakat standartlarını bozduğu ve kamu yatırımlarında daha düşük altyapı kalitesine neden olduğu ifade edilmektedir (Everett et al., 2007: 514). Günümüzde hem kamu hem de özel sektörlerde yaşam şekli haline gelen yozlaşma uygulamaları bir işletmenin faaliyette bulunduğu sektör ne olursa olsun (kamu, özel, hükümet dışı organizasyon vb.) eğer kaliteli hizmet veya ürün üretiminde tekelci yapı var ise ve yeterli bir hesap verme mekanizması da bulunmuyorsa yozlaşma meydana gelmesi olasıdır (Gürbüz ve Dikmenli, 2009: 234).

Yozlaşmanın ticareti ve ekonomik gelişmeyi engellediği hakkında Getz ve Volkema (2001: 23)' nın yaptığ1 çalışmada; yozlaşma değişkeni için Yolsuzluk Algı Endeksi (Corruption Perception Index-CPI) kullanılmş ve elde edilen bulgulara göre; belirsizlikten kaçınma yozlaşmayı anlamlı düzeyde azaltmakta ve diğer bir değişken olan kişi başına GSMH ise yozlaşma artışı ile birlikte azalmaktadır. Bir ülkedeki yozlaşma düzeyi ile ekonomik sistem arasında yakın bir ilişki olduğunu açıklayan bir başka çalışma 28 AB üyesi ülke ve Türkiye için 2014 yılı verileri kullanılarak yatay kesit analiz yöntemi ile gerçekleştirilmiştir. Söz konusu çalışmada Konu ve Ata (2016: 203); bağımlı değişken olarak yolsuzluk algısını, bağımsız değişkenler olarak ise kişi başına düşen milli gelir, ekonomik büyüme oranı, enflasyon oranı ve ekonomik özgürlük değişkenlerini ele almıştır. Modelin tahmin sonuçlarına göre, ekonomik büyüme değişkeninin yozlaşma üzerinde anlamlı ve pozitif yönlü bir etkiye sahip olduğu sonucuna ulaşılmıştır. Bu durumda ekonomik büyümedeki bir artış yolsuzluk endeksi üzerinde bir artışa (yozlaşmanın azalmasına) neden olmaktadır. Ayrıca ekonomik özgürlükler ile yozlaşma arasında istatistiksel olarak anlamlı ve pozitif yönlü bir ilişki bulunmaktadır. Ekonomik özgürlükler endeksindeki bir artış yozlaşma üzerinde artışa (yozlaşmanın azalmasına) neden olmaktadir.

Yozlaşma ve ekonomik değişkenler ilişkisini vurgulayan pek çok çalışma mevcut olup özellikle özel sektör girişimciliği üzerindeki etkisinin araştırıldığı çalışmalarda, özel sektör üzerindeki etki; özel sektörün risk ve belirsizlik sevmediğinden hareketle açıklanmakta ve yozlaşmanın özel sektör girişimciliği üzerinde negatif etkisi olduğu ele alınmaktadır (Aidis et al., 2012; Dutta and Sobel, 2016). Söz konusu çalışmalar genel olarak politika yapıcıların yolsuzlukla mücadele için neler yapması gerektiği üzerinde dururken, özel sektör girişimciliği teşvik çabalarının devamlığının altı çizilmektedir (Mohamadi et al., 2017: 50).

Yozlaşma ile bir başka ekonomik değişken olarak büyüme dikkate alındığında, ekonomik büyüme üzerindeki negatif etkiler; Pellegrini and Gerlagh (2004) ile Meon and Sekkat (2005) tarafından vurgulanmaktadır. Yine 2005-2015 dönemi için Endonezya' nın ele alındığı bir başka çalışmada, yozlaşmanın daha yüksek olduğu illerde yerel düzeyde ekonomik büyümenin kötüleştiği tespit edilmiştir (Alfada, 2019: 1). 2001 yılı için 91 ülkeyi kapsayan bir çalışmada da kişi başına düşen gelirin 
yüksek olduğu ülkelerde yozlaşma düşük çıkmakta ve aynı çalışmada eğitim düzeyinin yüksek olmasının da yozlaşmayı düşürdüğü ortaya çıkmıştır. Buna karşın gelir dağılımındaki eşitsizliğin ve enflasyonun yozlaşma üzerindeki etkisi orta dereceli tespit edilmiş ve enflasyon yükseldikçe yozlaşmanın arttı̆̆ı saptanmıştır. Araştırmadan çıkan bir başka ilginç sorun, ekonominin büyüklüğünün yozlaşma üzerinde bir etkisi olmadığı şeklindedir (Sayan ve Kışlalı, 2004:46).

Yozlaşma ve ekonomik büyüme arasındaki ilişkiyi inceleyen pek çok araştırmada elde edilen sonuçlar benzer niteliktedir. 2012-2018 döneminde 175 ülke için yozlaşma ve ekonomik büyüme arasındaki bağın araştırıldığ çalışmada uzun dönem etkisi olarak yozlaşma, kişi başına düşen reel GSYİH' nın yüzde 17 oranında azalmaya neden olmuştur (Gründler and Potrafke, 2019: 1). Johnson, Kaufmann ve Zoido-Lobatón (1999) ise, 49 Latin Amerika, OECD ve geçiş ekonomisinden oluşan genişletilmiş bir veri setini kullanarak daha büyük bir gayri resmi ekonomiye sahip ülkelerin daha yavaş büyüme eğiliminde olduğunu tespit ederek, bu çerçeve yozlaşmanın ve etkinsiz vergi idaresinin daha düşük büyümeye neden olabileceğini ortaya koymuşlardır.

Bu konudaki pek çok araştırmadan bir diğeri ise Tanzi ve Davoodi (1997) tarafından kaleme alınmıştır ve yaptıkları çalışma ile 1 puanlık yolsuzluk seviyesi, GSYİH düzeyinde 1,5 oranında azalmaya yol açmakta ve vergi gelirlerinin GSYH içindeki payı ise 2,7 puan azalmaktadır. Dolayısıyla bütçe gelir kaynaklarının yozlaşmanın artmasından daha olumsuz etkilendiğini ispat etmişlerdir.

Yozlaşmanın kamu maliyesi üzerindeki etkisine gelindiğinde ise, net etkisi hakkında Tanzi (1998: 113), kamu açıklarının artışına neden olacağını ifade etmektedir. Kamu harcamaların ve vergi sisteminde etkinlik azalacağından bütçe açığının belirleyen kamu harcama ve gelir düzeylerini etkileyeceği yönündedir. Kamu maliyesi üzerindeki etkileri hakkındaki bir diğer çalışmada ise; elde edilen vergi gelirlerini azaldığı, kamu harcamalarını olumsuz etkileyerek etkin devlet harcamalarının verimliliğinin düştüğü ifade edilmektedir (Ghosh and Neanidis, 2010: 25). Benzer şekilde bürokratik anlamda yozlaşmanın kamu harcamalarının etkinliğini azalttığını ifade eden Monte ve Papagni (2001: 1), yozlaşmanın büyüme üzerindeki olumsuz etkisini İtalya örneğini dikkate alarak 1963- 1991 dönemini kapsayan bir model ile test etmişler. Bürokratik süreçte rüşvet gibi politik yozlaşmaların etkisiyle politikacılar, büyük yatırımlar yapmak yerine büyük ölçüde üretken olmayan projelere yönelebilmektedir (Mauro, 1998: 277-278).

Bunun yanında yozlaşma ile birlikte rant arama davranışı potansiyeli (rant talep etme gücü) karar vericilerin yatırım teşviklerini azaltmakta çünkü rant arayışı, yenilikçi çabalar için belirsizliği artırmaktadır (Jain, 1998 :27). Lobicilik faaliyeti ile kendi lehlerine karar aldırmaya çalışan gruplar kamusal kaynakların etkin kullanımının önünde engel olacaktır ve en ciddi tehlike bir süre sonra yolsuzluk yavaş yavaş kendini meşrulaştıracaktır. Bununla birlikte devletin ekonomiye müdahalelerinin artmasıyla bürokrasi ve kırtasiyecilik de artış göstermektedir. Bu durumda bürokrasinin genişlemesinin yozlaşma ve kamusal etkililik ile ilişkisi dikkat çekmektedir. Genel olarak kabul gören anlayış ile bürokrasi engeline takılan vatandaşlar ister istemez rüşvet ve yolsuzlukla işlerini yapmaya çalışmaktadır.

Yozlaşma ile kamu kesiminin büyüklügünü birlikte değerlendirdiğimizde, ekonomik özgürlüklerin artması ekonomik mübadele sürecinin, bürokrasinin ve hükümet müdahalelerinin azalması ifade edilmektedir. Dolayısılla ekonomik özgürlüğün boyutu ile bir ülkedeki yolsuzluğun düzeyi araştırılmıştır. Goel ve Nelson'un (2005: 122-127) çalışmasında ekonomik özgürlüklerin artması, hükümet müdahalelerinin azalması yani yolsuzluk düzeyinin azalması olarak yorumlanmış ve gerçekleştirilen regresyon modellerinin tümünde ekonomik özgürlükler arttıkça yolsuzluk düzeyleri azalmıştır. Bu çalışmada ayrıca kamu politikalarının yolsuzluk üzerindeki etkisi tahmin edilmeye çalışılmış ve kamu kesimi büyüklüğünün yolsuzlukları arttırdı̆̆ 1 ifade edilmiştir.

Dolayısıyla kamusal hizmetlerde etkililik ülkeler için önemli bir gösterge haline gelmektedir. Burada bahsedilen kamu hizmetinde etkililik, hizmetin amacına uygun sunulabilme durumunu tarif ederken, etkinlik harcanan kaynak ve sağlanan kamusal fayda arasındaki ilişki ile ilgilidir (Ekşi, 2016). Bunu sağlayabilmek ise yozlaşma ile mücadelede kamu sektörü için etkinlik ve etkililik arayışlarını kuvvetlendirmektedir.

Bu konuda özellikle kamu bütçesine șeffaf bir erişim sağlanarak asimetrik bilgi azaltılabilir (Arifin and Purnomowati, 2017: 467) ve idari reformlar ile kurumlar arası koordinasyon, hesap verebilirliği artıracak mekanizmalar kurmak, soruşturma ve kovuşturmaları geliştirmek ve her türlü şüphenin açıklığa kavuşturulması için usulsüzlükler ile yasa dışılığı önlemek için tasarlanmış yasal reformlar yürürlüğe koymak gerekli ve önemlidir (Klitgoard, 1998: 6). Benzer şekilde Ackerman (1997: 18), kamu sektöründe kamusal politikalarda daha şeffaf bir süreç oluşturmanın yozlaşmayı önleyebileceğini ileri sürmektedir.

Buradan hareketle OECD ülkelerinin baz alındığı bu çalışmada, yozlaşma ile kamu ekonomisi ve özel ekonomi ilişkisi araştırılmak istenmiş ve kamusal etkililik ile kişibaşına GSYİH ve işsizlik göstergelerinden yararlanılmıştır. Söz konusu çalışmada 2004-2015 döneminde OECD ülkeleri için panel veri analizi kullanılmıştır. Yozlaşma değişkeni için Dünya Bankası'nın Yolsuzluk Algı Endeksi kullanılmıştır. Elde edilen sonuçlar itibariyle çalışma hem yozlaşma hem de diğer değişkenler olan kişibaşına GSYİH, kamusal etkililik skorları ve işsizlik oranlarını birlikte değerlendirildiğinden literatüre katkı sağlayabileceği tahmin edilmektedir. 


\section{AMPÍRIKK MODEL VE VERİ SETI}

Ekonomi literatüründe yozlaşma olgusunu ele alan çok sayıda çalışma mevcuttur. Bu çalışmalarda özellikle yozlaşma ve ekonomik büyüme üzerinde odaklanılmıştır. Genel olarak yozlaşmanın temel etkenleri üzerinde durulmakta ve bazı kurumsal yapı belirleyicileri ile ilişkisi araştırılmıştır. Çok az sayıda çalışmada, yozlaşma ve kamu ekonomisi ilişkisi araştırılmış olmakla birlikte, OECD ülkeleri nezdinde kamusal etkililiği dikkate alan çalışmaya rastlanmamıştır. Bu bağlamda çalışmanın literatüre katk1 sağlayacağı tahmin edilmektedir. Kamusal etkililik ve büyümenin (kişibaşına GSYİH) yozlaşmaya etkisini ölçmek amacıyla yapılan bu çalışmada, 2004-2015 döneminde OECD ülkeleri için panel veri analizi kullanılmıştır.

Tablo 1: Kullanılan Değişkenler ve Kaynakları

\begin{tabular}{|c|c|c|}
\hline Kullanılan Veri & Değișken Adları & Kaynak \\
\hline Yolsuzluk Alg1 Endeksi & YAE & $\begin{array}{l}\text { Uluslararas1 Şeffaflık Örgütü (TI) } \\
\text { https://www.transparency.org/) }\end{array}$ \\
\hline Kamusal Etkililik Skorları & $\mathrm{KE}$ & Dünya Bankası (https://databank.worldbank.org) \\
\hline Kişibaşına GSYİH & KGSYİH & $\begin{array}{l}\text { OECD } \\
\text { (https://stats.oecd.org/) }\end{array}$ \\
\hline İşsizlik Oranları & İO & $\begin{array}{l}\text { OECD } \\
\text { (https://stats.oecd.org/) }\end{array}$ \\
\hline
\end{tabular}

Çalışmada veri seti, her bir yatay kesit için eşit sayıda gözlem sayısını içerdiği için dengeli panel verisi özelliğini taşımaktadır. Çalışmada $\mathrm{t}<\mathrm{n}$ olduğu ve verinin farklı ülkeleri temsil ettiği için hata terimleri arasındaki ardışık bağımlılığ belirten otokorelasyon incelenmemiştir.

Değişkenler birinci dereceden farkları alındığında durağan hale geldiğinden logaritmaları alınmamıştır. Sadece kişibaşına GSYİH'yı ifade eden KGSYİH değişkeninin logaritmik değeri alınmıştır. Çalışmada bağımlı değişken olarak yozlaşma ele alınmış ve bağımsız değişkenleri temsilen kamusal etkililik skorları, ekonomik büyümeyi temsilen kişibaşına GSYİH ve işsizlik oranları kullanılmıştır. Modelin denklemi aşağıda verilmiştir;

$$
\Delta \mathrm{YAE}_{i n=} \alpha_{i n}+\beta \Delta \log \mathrm{KGSYIH}_{i n}+\beta \Delta \mathrm{KE}_{\text {in }}+\beta \Delta \mathrm{IIO}_{i n}+£_{\text {in }}
$$

$\mathrm{YAE}_{\text {in }}$ i ülkesinde $\mathrm{n}$ dönemindeki yolsuzluk alg1 endeksini

logKGSYİH ${ }_{\text {in }}=\mathrm{i}$ ülkesinde $\mathrm{n}$ dönemindeki logaritmik kişi başına milli gelir

$\mathrm{KE}_{\text {in }}=\mathrm{i}$ ülkesinde $\mathrm{n}$ dönemindeki kamusal etkililik skorlarını

İO ${ }_{\text {in }}=\mathrm{i}$ ülkesinde $\mathrm{n}$ dönemindeki işsizlik oranlarını

$\alpha_{i n}=$ sabit etkiyi, $€_{i n}=$ modelin kalıntılarını ifade ederken $(\triangle)$ ise fark işlemcisini ifade etmektedir.

Modelde bağımlı değişken olarak kullanılan yozlaşma için "Yolsuzluk Algılama Endeksi” kullanılmış olup, bu indeks Uluslararası Saydamlık Örgütü tarafından hazırlanmıştır. Yolsuzluk algılama endeksi ortaya koyduğu değerler, ülkelerdeki yolsuzluk algısının düzeylerini göstermekte ve buradaki bilgileri elde etmek için yapılan araştırmada, her ülke ile ilgili olarak en az dört ayrı anket uygulanmaktadır. Yolsuzluk Algılama Endeksi, 0 ile 100 arasında değerlerden oluşmaktadır. Buna göre; 0, en yüksek yolsuzluğu; 100 ise en düşük yolsuzluk düzeyini ifade etmektedir. Bir diğer değişken ise kamusal etkililiktir. Kamusal etkililik Dünya Bankası Yönetişim Göstergeleri veri setinde yer alan 182 ülke için belirlenmiş olan bir göstergedir. Dünya Yönetişim Göstergeleri, 35 farklı kaynaktan üretilen 340 değişkene dayalı olarak firma araştırmaları ve ticari bilgi sağlayıcıları, kamu kuruluşları, sivil toplum örgütleri, hanehalkı, da olmak üzere farklı gruplara dayanarak oluşturulmuştur (Kaufmann vd. 2008: 8). Kişibaşına GSYİH ve işsizlik verileri de dahil olmak üzere model kullanılan tüm değişkenler, Dünya Bankası, Uluslararası Şeffaflık Örgütü (TI), TÜİK ve Hazine ve Maliye Bakanlığı Strateji Geliştirme Başkanlığı'ndan elde edilmiştir. Veriler E-views 10.0 programı ve STATA 14 kullanılarak analiz edilmiştir. Çalışmada yatay kesit boyutu (n) 33 olup, zaman boyutu (t) 12 yıldır.

Çalışmada bazı değişkenlerde (YAE ve KE için) yatay kesit bağımlılığı tespit edilmediğinden Im, Pesaran ve Shin (2003) ile Levin, Lin, Chu (2002) birim kök testleri kullanılmıştır, diğer iki değişken için ise yatay kesit varlığından dolayı ikinci nesil birim kök testi kullanılmıştır. Sonrasında Bias-Adjusted CD Test sonucu, hem "t" hem "n” büyükken kullanılabildiğinden, bu testin sonuçlarının kullanılmasına karar verilerek yatay kesit bağımlılı̆̆ını dikkate alan eşbütünleşme testlerinin tercih edilmesi gerektiği görülmüştür. Seriler arasında yatay kesit bağımlığı tespit edildiğinden çalışmada, Westerlund (2007) panel eşbütünleşme testinin uygulanmasına karar verilmiş ve AMG tahmincisi kullanılmıştır. Yatay kesit bağımlılığının olduğu durumlarda eğer eğim katsayıları homojen ise CUP-FM ve OLS tahmincileri dikkate alınırken, heterojen olduğu durumda ise CCE (Common Correlated Effects) ve AMG (Augmented Mean Group) tahmincileri kullanılmaktadır. Dolayısıyla çalışmada AMG tahmincisi tercih edilmiştir. 


\subsection{Ampirik Analiz}

Panel veride yatay kesit bağımlılı̆̆ını test etmek için üç seçenek mevcut olup bunlar; Pesaran (2004) $C D_{L M}$ testi, Breusch Pagan (1980) $C D_{L M 1}$ testi ve Pesaran (2004) $C D_{L M 2}$ testleridir. $\mathrm{n}<\mathrm{t}$ durumunda $C D_{L M 1}$ ve $C D_{L M 2}$ testleri kullanırken, $\mathrm{t}<\mathrm{n}$ durumunda ise $C D_{L M}$ testi kullanılır (Çınar, 2010: 594). Çalışmada 12 yıllık veri, 33 yatay kesit ile değerlendirildiğinden yatay kesit bağımlılığına karar verirken Pesaran (2004) $C D_{L M}$ testi kullanılacaktır

Tablo 2: Yatay Kesit Bağımlılığı

\begin{tabular}{|c|c|c|c|c|c|}
\hline & & CDLM1 (BP,1980) & $\begin{array}{c}\text { CDLM2 } \\
(\text { Pesaran, 2004) }\end{array}$ & $\begin{array}{c}C D L M \\
\text { (Pesaran, 2004) }\end{array}$ & $\begin{array}{c}\text { Bias-Adjusted } \\
\text { CD Test }\end{array}$ \\
\hline \multirow{2}{*}{ YAE } & İstatistik & 806.07 & 8.557 & 2.078 & 6.907 \\
\hline & Olasılık & 0.000 & 0.000 & 0.30 & 0.000 \\
\hline \multirow{2}{*}{ KE } & İstatistik & 704.65 & 5.436 & 3.204 & 3.768 \\
\hline & Olasılık & 0.000 & 0.000 & 0.10 & 0.002 \\
\hline \multirow{2}{*}{$\operatorname{logKGSYİH}$} & İstatistik & 1803.54 & 39.252 & 34.565 & 37.602 \\
\hline & Olasılık & 0.000 & 0.000 & 0.000 & 0.000 \\
\hline \multirow{2}{*}{ İO } & İstatistik & 1682.70 & 35.533 & 34.718 & 33.863 \\
\hline & Olasılık & 0.000 & 0.000 & 0.000 & 0.000 \\
\hline
\end{tabular}

Analize dahil edilen dört değişkenden ikisi için boş hipotezi anlamlı olarak kabul edilir ve yatay kesit bağımlılığının olmadığı sonucuna ulaşılmıştır diğer iki değişken için ise boş hipotezi anlamlı olarak reddedilir ve yatay kesit bağımlılığının olduğu sonucuna ulaşılmıştır. Bu durumda p >0.05 olan YAE ve KE değişkenleri için boş hipotezi anlamlı olarak kabul edilir ve yatay kesit bağımlılığının olmadığı sonucuna ulaşılırken, $\operatorname{logKGSYİH~ve~İO~değişkeleri~için~ise~} \mathrm{p}<0.05$ olduğundan yatay kesit bağımlılı̆̆ının olduğu sonucuna ulaşılmıştır.

Bai ve Ng (2001,2004), Moon ve Perron (2004), Phillips and Sul (2003), CADF-CIPS, Choi (2002), O'Connell (1998) ve Chang $(2002,2004)$ testleri ikinci nesil birim kök testleridir (Hurlin ve Mignon, 2006, s. 3). Bunlar arasında Peseran (2007)'ye ait CIPS testine yer verilmiştir. Eşbütünleşme testine karar verirken ise Bias-Adjusted CD'ne bakılmıştır çünkü bu test hem “t”" hem "n" büyükken kullanılabildiğinden bu testin sonuçları kullanılanilir olmaktadır ve oluşturulan ekonometrik model için yatay kesit bağımlılığını dikkate alan eşbütünleşme testleri tercih edilecektir.

\subsubsection{Birim Kök Testi Sonucu}

Panel birim kök analizinde, yatay kesit bağımlılı̆̆ı olup olmaması durumuna göre birinci nesil ya da ikinci nesil birim kök testlerinin hangisinin dikkate alınacağı belirlenir. Birinci nesil birim kök testleri olarak adlandırılan testler yatay kesit bağımlılığını dikkate almazken, ikinci nesil birim kök testleri yatay kesit bağımlılığını dikkate alabilmektedir. Analizde yatay kesit bağımlılığı sadece 2 değişken (logKGSYİH ve İO) için söz konusudur. Eğer serilerde yatay kesit bağımlılık tespit edilmişse ikinci kuşak testler kullanılmalıdır (Çınar, 2010: 594).

Çalışmada kullanılan YAE ve KE değişkenlerinin yatay kesit bağımlılı̆̆ı olmadığından durağanlıklarına Im, Pesaran ve Shin (2003) ile Levin, Lin, Chu (2002) birim kök testleri ile bakılmıştır. Birim kök testlerinin uygulanması ampirik analiz sonuçlarının sağlıklı olması için önem arz etmektedir. Im, Pesaran ve Shin (2003: 55); sıfır hipotezi "seriler durağan değildir", alternatif hipotez "serilerden en az biri durağandır" şeklindedir. Im, Peseran, Shin (2003) testi, trendli ve sabitli olmak üzere iki aşamalı bir denklemine dayanmaktadır. Levin, Lin, Chu (2002) ise bireysel birim kök testlerinin alternatif hipotezlere karş1 sınırlı gücünün olmasını tartışmıştır. Sıfır hipotezi her bir bireysel zaman serisinin birim kök içerdiği, alternatif hipotez ise her bir zaman serisi durağandır şeklinde kurulmaktadır (Baltagi, 2005: 240).

Tablo 3: Birim Kök Testi Sonuçları (Im, Peseran, Shin -2003 testi) (YAE ve KE Değişkenleri İçin)

\begin{tabular}{|c|c|c|c|c|c|c|c|}
\hline \multirow{5}{*}{ 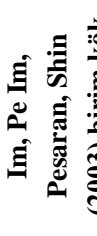 } & \multirow{5}{*}{ 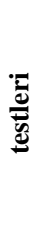 } & & Model & $\begin{array}{c}\mathrm{p} \\
\text { (düzey) }\end{array}$ & $\begin{array}{c}\text { T ist. } \\
\text { (düzey) }\end{array}$ & $\begin{array}{c}\mathrm{p} \\
\text { (1. fark) }\end{array}$ & $\begin{array}{c}\mathrm{T} \text { ist. } \\
\text { (1. fark) }\end{array}$ \\
\hline & & \multirow[t]{2}{*}{ YAE } & Sabitli & 0.006 & $-2.472 *$ & 0.000 & $-4.154^{*}$ \\
\hline & & & Sabitli-trendli & 0.477 & -0.056 & 0.144 & -1.059 \\
\hline & & \multirow[t]{2}{*}{$\mathrm{KE}$} & Sabitli & 0.097 & -1.295 & 0.000 & $-6.600 *$ \\
\hline & & & Sabitli-trendli & 0.024 & $-1.966 * *$ & 0.003 & $-2.731 *$ \\
\hline
\end{tabular}

Not: *:\%1 düzeyinde anlamlı; **: \% 5 düzeyinde anlamlı

Tablo 4: Birim Kök Testi Sonuçları ( Levin, Lin, Chu -2002 testi) (YAE ve KE Değişkenleri İçin)

\begin{tabular}{|c|c|c|c|c|c|c|}
\hline \multirow{7}{*}{ 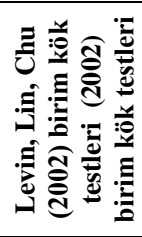 } & & Model & $\begin{array}{c}\mathbf{p} \\
\text { (düzey) }\end{array}$ & $\begin{array}{c}\text { T ist. } \\
\text { (düzey) }\end{array}$ & $\begin{array}{c}\mathbf{p} \\
\text { (1. fark) }\end{array}$ & $\begin{array}{c}\text { T ist. } \\
\text { (1. fark) }\end{array}$ \\
\hline & \multirow[t]{3}{*}{ YAE } & Sabitli & 0.000 & $-7.154 *$ & 0.000 & $-6.426 *$ \\
\hline & & Sabitli-Trendli & 0.001 & $-2.935 *$ & 0.000 & $-7.235^{*}$ \\
\hline & & Sabitsiz-Trendsiz & 0.000 & $-3.148 *$ & 0.000 & $-10.378 *$ \\
\hline & \multirow[t]{3}{*}{$\mathrm{KE}$} & Sabitli & 0.004 & $-2.649 *$ & 0.000 & $-11.669 *$ \\
\hline & & Sabitli-Trendli & 0.000 & $-12.896 *$ & 0.000 & $-9.279 *$ \\
\hline & & Sabitsiz-Trendsiz & 0.002 & $-2.819 *$ & 0.000 & $-16.327 *$ \\
\hline
\end{tabular}


Not: *:\%1 düzeyinde anlamlı; **: \% 5 düzeyinde anlamlı

Birim kök testi sonuçları Tablo 3 ve 4 'te verilmiştir. Tablo incelendiğinde, çalışmada kullanılan seriler büyük ölçüde seviyelerinde durağanlık sağlamış ancak bazı değişkenler için seviyede durağanlık olmadığından tüm serilerin birinci farkları alındığında serilerin durağan oldukları tespit edilmiştir. Diğer bir ifadeyle serilerin I(0) iken I(I) oldukları belirlenmiştir. Koentegrasyon sınaması için tüm değişkenlerin aynı derece durağan olmaları gereklidir. Bu sağlandığı için eşbütünleşme sınaması yapılacaktır. Tüm serilerin durağanlı̆̆ını hesaplayan ikinci kuşak birim kök testi olan CIPS testi için ise test istatistiği aşağıdaki denklemde gösterilmektedir:

$\mathrm{CIPS}=\frac{1}{N} \sum_{i=1}^{N} C A D F_{i}$

CIPS testinde paneli oluşturan tüm yatay kesit birimlerinde H0: birim kök vardır. CIPS istatistik değeri Pesaran (2007) kritik tablo değerleriyle karşılaştırılır. Eğer kritik tablo değerleri CIPS test istatistiği değerlerinden büyükse H0 reddedilmekte ve panel serilerinin bütün olarak durağan olduğu kabul edilmektedir.

Tablo 5. CIPS Testi Sonuçları (İO ve LogKGSYH Değişkenleri için)

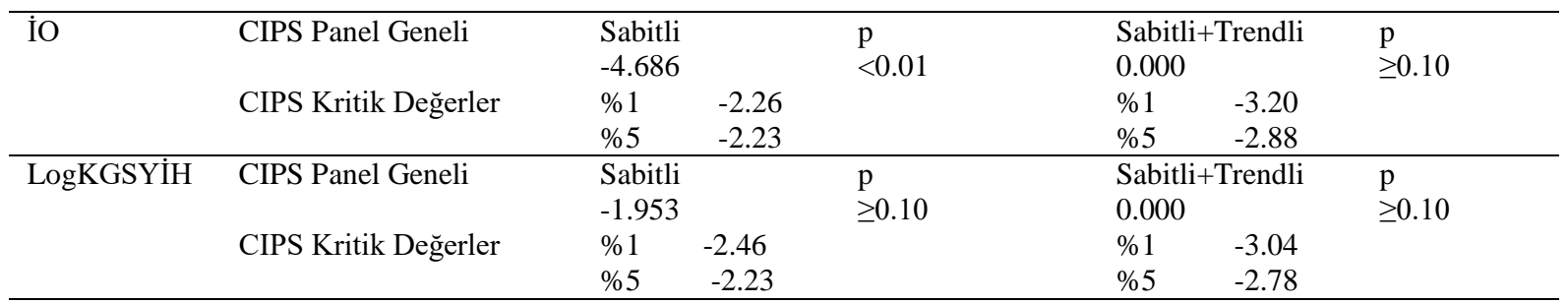

Tablo 5 incelendiğinde işsizlik değişkeni için $\mathrm{p}<0.05$ olduğundan HO (birim kök vardır) red olacaktır. Bu durum sadece sabitli test için geçerlidir, sabitli ve trendli bir arada test yapıldığında ise, $\mathrm{p}>0.05$ olduğundan HO kabul edilmekte ve birim kök var olduğu tespit edilmektedir. Kişibaşına GSYH değişkeninde ise hem sabitli hem de sabitli trendli testte birim kök varlığ1 kanıtlanmaktadır. Dolayısıyla serilerin sabitli trendli testleri baz alındığında, düzeyde durağan olmadıkları I(1) görülmüştür. Dolayısıyla her ikisi için de analizde birinci derece farkları alınarak analizlere devam edilmiştir. Değişkenlerin düzeyde I(0) durağan olmadıkları, farkı alınan serilerin durağan olduğu görülmektedir. Bütün değişkenler I(1) düzeyinde durağandır. Seviyede durağan olmayan ancak farkı alındığında aynı düzeyde durağan olan serilerin kendi aralarındaki uzun dönemli ilişkiyi tespit etmek için Eşbütünleşme (Koentegrasyon) testi yapılmaktadır.

\subsection{Eșbütünleșme Testi}

Değişkenler arasında eşbütünleşme ilişkinin varlığını sınamak için uygun panel eşbütünleşme testinin belirlenmesi gerekmektedir. Yapılan yatay kesit bağımsızlık testleri ile yatay kesit bağımlılığını dikkate alan eşbütünleşme testlerinin tercih edilmesi gerektiği görülmüştir Seriler arasında yatay kesit bağımlığı tespit edildiğinden çalışmada, Westerlund (2007) panel eşbütünleşme testinin uygulanmasına karar verilmiştir. Westerlund (2007) testi koşullu bir hata düzeltme modelinde, hata düzeltme teriminin sıfıra eşit olup olmadığı sonucunu ortaya koyarak sıfır hipotezini test etmektedir.

Tablo 6.: Westerlund (2007) Eşbütünleşme Testi Sonucu

\begin{tabular}{|c|c|c|c|c|}
\hline Bağımlı değişken & Bağımsız değişkenler & İstatistik & Olasılık & Dirençli olasılık \\
\hline \multirow[t]{3}{*}{ YAE } & İO (Model 1) & -0.068 & 0.089 & $0.010 * *$ \\
\hline & KE (Model 2) & -0.290 & 0.190 & $0.044 * *$ \\
\hline & LogKGSYİH (Model 3) & -0.000 & 0.228 & $0.000 *$ \\
\hline
\end{tabular}

Westerlund (2007) eșbütünleşme testi sabitli modele göre yapılmıștır. Sıfır hipotezi “Eşbütünleşme Yoktur” şeklindedir. *,** işaretleri sirasıyla $\% 1, \% 5$ anlamlılık düzeyini ifade etmektedir.

Tablo 6 incelendiği zaman serilerin ilişkiyi tespit etmek için yaptıpılan Eşbütünleşme (Koentegrasyon) testi sonucuna göre yozlaşmanın bağımlı değişken olduğu tüm modellerde değişkenler arasında eşbütünleşme ilişkisi vardır. Uygulanan Westerlund (2007) panel eşbütünleşme testi sonuçlarına göre H0 hipotezinin reddedildiği ve değişkenler arasında uzun dönemli bir eşbütünleşik ilişkinin olduğuna dair sonuçlar elde edilmiştir. Panelin heterojenlik sınamasında ise panelin heterojen olduğu kanıtlandığından grup ortalama istatistiklerine dikkat edilmelidir eğer homojen olsaydı panel istatistiklerine daha fazla güvenilmelidir (Tatoğlu, 2017:200-203). Çalışmada kullanılan değişkenlerin eğim parametreleri heterojen olması ve değişkenlerin yatay kesit bağımlılığına sahip olması dolayısıyla Westerlund(2007) panel eşbütünleşme testi sonuçlarını gösteren tabloda, grup ortalama istatistiklerinin dirençli olasılık değerleri dikkate alınmalıdır. Bu testlerin dirençli olasılık değerlerine bakıldığında "Eşbütünleşme Yoktur" şeklindeki sıfır hipotezinin reddedildiği ve serilerin eşbütünleşik olduğu sonucuna varılmıştır

\subsection{Panel AMG Tahmincisi}


Westerlund (2007) panel eşbütünleşme testi ile eşbütünleşme kanıtlandıktan sonra eşbütünleşik ilişkinin parametre katsayıları tahmin edilmiștir. Yatay kesit bağımlılığını dikkate alan AMG tahmincisi kullanılmıștır.

Tablo 7: Panel AMG Uzun Dönem Parametre Tahmin Sonuçları

\begin{tabular}{|c|c|c|c|}
\hline $\begin{array}{l}\text { Bağımlı değişken } \\
\text { YAE }\end{array}$ & Katsayı & Std. Hata & Olasilık \\
\hline LogKGSYİH & 0.384 & 0.023 & $0.00 *$ \\
\hline İO & -0.012 & 0.014 & 0.37 \\
\hline KE & 2.560 & 0.126 & $0.00 *$ \\
\hline $\mathrm{C}$ & & & \\
\hline
\end{tabular}

Tablo 7 incelendiğinde, kişibaşına GSYİH, yozlaşmayı pozitif bir katsayı değeri ile etkilemektedir ancak bu etki negatif yönlüdür çünkü katsayı değerinin pozitif çıkması yani yolsuzluk endeksi üzerinde bir artışın olması yolsuzluğun azalmasına işaret etmektedir. Dolayısıyla kişibaşına GSYİH değeri arttıkça \%1 anlamlılık düzeyinde analize dahil edilen ülkeler açısından yozlaşma düzeyi gerilemektedir. Dolayısıyla ekonomi büyürse, yozlaşma dediğimiz bozulma da azalmaktadır. Kişibaşına GSYİH' daki 1 birimlik artış \% 0.38 düzeyinde yozlaşmayı azaltmaktadır. Bir diğer değişken olarak kamusal etkililik yozlaşma üzerinde anlamlı ve pozitif bir etkiye sahiptir. Yolsuzluk endeksi üzerinde bir artışın olması, yozlaşmanın azaldığına işaret ettiğine göre, kamusal etkililik artarsa yozlaşmanın azaldığı sonucuna işaret etmektedir. Buna göre \%1 anlamlılık düzeyinde kamusal etkililik düzeyi 1 birim artarsa \%2.56 düzeyinde yozlaşmayı azaltmaktadır. Yozlaşmanın bağımlı değişken olarak ele alındığı regresyon modelinde bir diğer bağımsız değişken olan işsizliğin ise negatif katsayı değeri olup anlamlı bir etkisi söz konusu değildir.

Yatay kesit bağımlılı̆̆ını dikkate alan AMG tahmincisinden elde edilen sonuçlara göre kişibaşına GSYİH ve kamusal etkililik değişkenlerinin katsayı değeri pozitif ve istatistiki açıdan anlamlıdır. Yolsuzluk endeksi üzerinde bir artışın olması yolsuzluğun azalmasına işaret ettiğine göre; analize dahil edilen ülkeler açısından uzun dönemde büyüme ve kamusal etkililik yozlaşmayı azaltmaktadır.

\section{SONUÇ}

Yozlaşma sorunu dünya üzerinde sadece gelişmekte olan ülkeleri değil gelişmiş ülkeleri de etkileyen ve yaygın bir şekilde görülen küresel bir problem olarak karşımıza çıkmaktadır. Genel olarak yozlaşma ile bir kişinin gayri resmi bir amaç için hem parasal hem de parasal olmayan özel bir kazanç sağlama durumu ile izah edilmektedir. Yozlaşma ile ilgili yapılan araştırmalar, çoğunlukla yozlaşmanın ekonomik etkileri üzerinde yoğunlaşmaktadır ve ulusların ekonomik büyüme ve gelişmesini engellediği ve dolayısıyla sosyal istikrara zarar verdiği ifade edilmektedir.

Yozlaşmanın kamu sektörü açısından sonuçları incelendiğinde ise, liyakat ve etik standartlarını bozduğu, kişisel çıkar sağlama gayesi ile kamu kesimi karar vericilerin ve bürokratların kamu yatırımlarında daha düşük altyapı kalitesine neden olacak tercihlerde bulundukları dikkat çekmektedir.

Yozlaşmanın belirleyici olduğu modellerde elde edilen bulgular arasında ekonomik büyüme üzerindeki etkilerin olumsuz olduğu neredeyse genel kabul görmektedir. Ancak kamusal etkililik ve bir diğer ekonomik gösterge olarak işsizliğin ele alındığı çalışmalar oldukça sınırlı olduğundan tasarlanan bu çalışma ile, yozlaşmanın ekonomik gösterge olarak kişibaşına GSYİH ve işsizlik ile ilişkisi yanında kamusal etkililik skorlarının da birlikte değerlendirildiği bir model tercih edilmiştir. Modelde bağımlı değişken olarak kullanılan yozlaşma için "Yolsuzluk Algılama Endeksi”" kullanılmış olup, bu indeks Uluslararası Saydamlık Örgütü tarafından hazırlanmıştır. 2004-2015 dönemini kapsayan ve OECD ülkeleri için ele alınan model için panel veri analizi kullanılmıştır.

Regresyon analiz sonuçları göstermektedir ki; yozlaşmanın bağımlı değişken olduğu modelde kişibaşı GSYİH değişkeni anlamlı ve pozitif katsayıya sahiptir. Katsayı değerinin pozitif çıkmıştır dolayısıyla kişibaşına GSYİH arttıkça yolsuzluk algı endeksi de artmaktadır. Yolsuzluk endeksi üzerinde bir artışın olması ise yolsuzluğun azalmasına işaret etmektedir dolayısıyla kişibaşına GSYİH arttıkça yozlaşma gerilemektedir. Kişibaşına GSYİH yozlaşmayı negatif yönlü etkilemektedir yani \%1 anlamlılık düzeyinde kişibaşına GSYİH arttıkça yozlaşma düzeyi gerilemektedir. Bununla birlikte söz konusu etki sadece \% 0.38 düzeyinde olup, düşük düzeyde gerçekleşmiştir, diyebiliriz.

Bir diğer ekonomik değişken olarak dikkate alınan işsizliğin ise negatif katsayı değeri olup anlamlı bir etkisi söz konusu değildir. Dolayısıyla işsizlik ile ilgili yorum yapılamamaktadır. Son olarak kamusal etkililik ile yozlaşma arasındaki katsayı değerine bakıldığında, pozitif değere sahip olduğu ve anlamlı bir etki olduğu görülmektedir. Buna göre \%1 anlamlılık düzeyinde kamusal etkililik düzeyi 1 birim artarsa \%2.56 düzeyinde yolsuzluk algı endeksini etkilenmektedir. Yolsuzluk endeksi üzerinde bir artışın olması, yozlaşmanın azaldığına işaret ettiğinden kamusal etkililik skoru yükseldiğinde yolsuzluk algı endeksi de artarak, yozlaşmanın azaldığı sonucuna işaret etmektedir. Genel olarak görülmektedir ki, analize dahil edilen 
ülkeler açısından bir ülkedeki kişibaşına GSYİH ve kamusal etkililik yozlaşmayı etkilemektedir. Bu etkiler literatürdeki bulgular ile uyuşmaktadır. Dolayısıyla yapılan çalıșma baz alınan ülkeler itibariyle, literatürü de destekler niteliktedir.

\section{KAYNAKÇA (REFERENCES)}

Ackerman, S. R. (1997). Corruption, Inefficiency and Economic Growth. Nordic Journal of Political Economy, 24, 3-20.

Aidis, R., Estrin, S. \& Mickiewicz, T.M.(2012). Size Matters: Entrepreneurial Entry and Government. Small Bus. Econ. 39 (1), 119-139.

Alfada, A. (2019). The Destructive Effect of Corruption on Economic Growth in Indonesia: A Threshold Model. Heliyon, 5, 1-14.

Arifin, T. \& Purnomowati, N. H. (2017). Political Cycle \& Rent-Seeking. International Journal of Business and Society, 18(3), 461-468.

Arvind K. Jain (Ed.) (1998). Economics of Corruption. Springer Science Business Media, LLC, New York.

Baltagi, B.H. (2005). Econometric Analysis of Panel Data (3rd edition). Chichester: John Wiley \& Sons Ltd.

Çınar, S. (2010). OECD Ülkelerinde Kişi Başına GSYIH Durağan M1?. Panel Veri Analizi, Marmara Üniversitesi İiBF Dergisi, 29(2), 591-601.

Del Monte, A. \& Papagni, E. (2001). Public Expenditure, Corruption, and Economic Growth: The Case of Italy. European Journal of Political Economy, 17,1-16.

Dutta, N. \& Sobel, R. (2016). Does corruption ever help entrepreneurship?. Small Bus. Econ. 47 (1), 179-199.

Ekşi, A. (2016). Kamu Hizmetinde Etkililik ve Etkinlik Tartışmaları Bağlamında 112 Acil Çağrı Hizmetlerinin Kötüye Kullanımı. Dokuz Eylül Üniversitesi, Sosyal Bilimler Enstitüsü Dergisi, 18(3), 387-408.

Everett, J., Neu, D., \& Rahaman, A.S. (2007). Accounting and The Global Fight Against Corruption. Accounting, Organizations and Society, 32(6), 513-542.

Getz, K.A. \& Volkema, R.J. (2001). Culture, Perceived Corruption and Economics: A Model of Predictors and Outcomes. Business and Society, 40(1), 7-30

Ghosh, S. \& Neanidis, K. C. (2010). Corruption in Public Finances, and the Effects on Inflation, Taxation, and Growth. Working Paper No. 10-14, Brunel University West London.

Goel, R.K. \& Nelson, M.A. (2005). Economic Freedom Versus Political Freedom: Cross Country Influences on Corruption. Australian Economic Papers, June, 44(2), 121-133.

Gründler, K. \& Potrafke, N. (2019). Corruption and Economic Growth: New Empirical Evidence ifo Working Paper, No. 309, Econstor,Ifo Institute. Gürbüz, S. \& Dikmenli, O. (2009). Örgütsel Açıdan Yolsuzluk: Kavramsal Yönü, Özelliği, İşletme Çevresi, Örgütsel Davranış ve Örgüt Mimarisi Bağlamında Bir İnceleme. Selçuk Üniversitesi Sosyal Bilimler Enstitüsü Dergisi 22, 219-237.

https://www.worldbank.org/en/topic/governance/brief/anti-corruption, 30. 05.2021.

Hurlin, C., \& Mignon, V. (2006). Second Generation Panel Unit Root Tests. HAL, halshs-00159842

Im, K., Pesaran, H. ve Shin, Y., (2003). Testing For Unit Roots in Heterogenous Panels", Journal of Econometrics, 115, 53-74.

Johnson, S., Kaufmann, D. \& Zoido-Lobaton, P. (1999). Corruption, Public Finances, and the Unofficial Economy", Policy Research Working Papers, Word Bank Group.

Karahan, M. (2019). Yolsuzlukla Mücadelede Denetimin Rolü. Manas Sosyal Araştırmalar Dergisi, 8(3), 2918- 2933.

Kaufmann, D. et al. (2008). Governance Matters VII: Aggregate and Individual Governance Indicators 1996-2007. Washington, DC.

Klitgaard, R. (1998). International Cooperation Against Corruption. Finance \& Development, March, 3-6.

Konu, A. \& Ata, A. Y. (2016), Yolsuzluk ve Ekonomik Özgürlük İlişkisi: AB Ülkeleri Üzerine Yatay Kesit Analizi, Niğde Üniversitesi İktisadi ve İdari Bilimler Fakültesi Dergisi, 9(1), 195-207.

Mauro, P. (1998). Corruption and The Composition of Government Expenditure. Journal of Public Economics 69, 263-279.

Meon, P-G. \& Sekkat, K. (2005). Does Corruption Grease or Sand the Wheels of Growth?. Public Choice, 122, 69-97.

Mohamadi, A., Peltonen, J. \& Wincent, J. (2017). Government Efficiency and Corruption: A Country-level Study with Implications for Entrepreneurship. Journal of Business Venturing Insights 8, 50-55.

Pellegrini, L., \& Gerlagh, R. (2004). Corruption's Effect on Growth and its Transmission Channels. Kyklos, 57, 429-456.

Pesaran M. H. (2007). A Simple Panel Unit Root Test In The Presence of Cross-Section Dependence. Journal of Applied Econometrics, 22, $265-312$.

Pesaran, M. H. (2004). General Diagnostic Tests for Cross Section Dependence in Panels.Cambridge Working Papers in Economics, 435.

Sayan, İ. Ö. \& Kışlalı M. (2004). Yolsuzluk Üzerine Ekonometrik Bir Çalışma. Amme İdaresi Dergisi, 37 (2), 31-50.

Tanzi, V. \& Davoodi, H. (1997). Corruption, Public Investment, and Growth. International Monetary Fund Working Paper, 97/139.

Tanzi, V. (1998). Corruption and The Budget: Problems and Solutions. Economics of Corruption. Springer Science Business Media, New York. (Ed. Arvind K. Jain), 111-128.

Tatoğlu, F. Y. (2017). Panel Zaman Serileri Analizi, Beta Basım Yayım Dağıtım A.Ş., İstanbul

Westerlund, J. (2007). Testing for Error Correction in Panel Data. Oxford Bulletin of Economics and Statistics, 69, 709-748. 